\title{
STUDI FENOMENOLOGI PENGEMUDI OJEK ONLINE PEREMPUAN DI KOTA BANDUNG DALAM KAJIAN FEMINISME
}

\author{
Irma Verasatiwi, Roro Retno Wulan \\ Universitas Telkom Bandung \\ irmaverasatiwi@gmail.com,rorowoelan28@gmail.com
}

\begin{abstract}
In today's era of modernization, women prefer to work rather than just housewives, although the work they choose is not suitable for women. Stereotypes in societies that still assume that women are unsuited for work are increasingly faded by women themselves. They demonstrate the existence and quality of self in order to be accepted in society and to get the recognition that they are worth equally by men. The development of the world of technology that increasingly facilitate the community in doing all activities to make other aspects of progress as well, including ease in the world of transportation. Currently, people easily order transportation such as taxis and motorcycles only by using the application. It is also what motivates women to show the existence and quality of self in the environment by doing a profession commonly done by men, which is an online motorcycle taxi driver. Although initially it is considered taboo, but the online motorcycle taxi drivers increasingly prove that it is not feasible to be a parameter in assessing women.
\end{abstract}

Keyword: female, motorcycle taxi online, feminism.

\section{PENDAHULUAN}

Di era globalisasi saat ini, perkembangan teknologi yang semakin pesat menuntut masyarakat untuk mengikuti perkembangan yang ada. Selain itu, perkembangan tersebut juga memberikan kemudahan kepada masyarakat dalam membantu kehidupan sehari-hari, sehingga masyarakat kini lebih memilih untuk menggunakan hal-hal yang praktis. Dengan kemunculan teknologi masa kini yang semakin pesat, memicu terjadinya tuntutan terhadap kebutuhan ekonomi. Perekonomian masyarakat menjadi semakin maju meskipun kebutuhan masyarakat pun semakin meningkat. Kemajuan ekonomi dan teknologi tersebut yang membuka peluang untuk menciptakan lapangan pekerjaan. Kemunculan transportasi online selain sebagai penunjang kemudahan masyarakat, juga sebagai lapangan pekerjaanbagi masyarakat lainnya. Kini masyarakat menggunakan transportasi online dalam kehidupannya sehari-hari, sehingga keberadaan trasnportasi online sangat dibutuhkan untuk menunjang mobilisasi yang dituntut cepat. Dibalik pesatnya pertumbuhan transportasi online saat ini, terdapat banyak cerita yang bermunculan dari para pengemudinya sendiri. Banyak kasus yang menyudutkan para pengemudi ojek online karena lingkungan masyarakat tidak dapat menerima keberadaan ojek online. Meskipun demikian, tidak menyudutkan niat para pengemudi ojek online untuk terus mencari nafkah dan memperjuangkan keberadaannya di lingkungan sosial agar dapat diterima oleh masyarakat khususnya para pengemudi ojek konvensional atau ojek pangkalan. 
Meskipun problematika pengemudi ojek online sangat kompleks, profesi tersebut tidak hanya dilakukan oleh para kaum lelaki saja. Peneliti menemukan fenomena di lingkungan sosial mengenai cukup banyaknya pengemudi ojek online yang dilakukan oleh para perempuan. Hal tersebut menjadi menarik diperbincangkan karena stereotip yang ada di masyarakat sendiri beranggapan bahwa biasanya profesi tersebut hanya dilakukan oleh para kaum lelaki, dan biasanya para kaum perempuan tidak cocok melakukan pekerjaan yang ada di lapangan seperti menjadi pengemudi ojek.

Stereotip bahwa perempuan tidak cocok bekerja di lapangan sudah menjadi pemikiran mendasar di lingkungan sosial. Perempuan dianggap hanya cocok untuk mengurus anak dan rumah tangga, tetapi dengan adanya tuntutan kehidupan yang semakin meningkat saat ini, stereotip tersebut banyak disanggah oleh kaum perempuan. Mereka memilih untuk tidak hanya mengurus anak dan rumah tangga, tetapi juga bekerja. Pekerjaan yang dipilih pun tidak selalu pekerjaan yang dianggap cocok untuk dilakoni perempuan, tetapi mereka juga memilih menjalani pekerjaan yang dianggap tabu untuk dikerjakan oleh kaum perempuan.

Emansipasi wanita yang kian lama kian digiatkan mendorong para kaum perempuan untuk menyetarakan keberadaannya dengan kaum laki-laki. Kaum perempuan merasa memiliki kekuatan yang setara dengan laki-laki sehingga mereka berusaha memperjuangkan haknya agar tidak dibedakan dengan laki-laki.
Salah satunya dalam menjalani sebuah profesi. Dengan latar belakang yang berbedabeda yang dimiliki oleh setiap orangnya, mereka berusaha menunjukkan eksistensinya dalam lingkungan sosial agar dianggap mampu untuk menjalani sebuah profesi yang setara dengan laki-laki. Identifikasi masalah dalam penelitian ini adalah bagaimana latar belakang yang melandasi para pengemudi ojek online perempuan ini memilih untuk menjalani profesi tersebut, serta bagaimana para pengemudi ojek online perempuan di kota Bandung mengkonstruksikan dirinya di lingkungan masyarakat.

Tujuan dari dibuatnya penelitian ini adalah untuk mengetahui bagaimana latar belakang yang melandasi para pengemudi ojek online perempuan ini memilih untuk menjalani profesi tersebut, juga untuk mengetahui bagaimana para pengemudi ojek online perempuan di kota Bandung mengkonstruksikan dirinya di lingkungan masyarakat.

Dalam penelitian ini, peneliti menggunakan studi fenomenologi untuk menjawab penelitian yang di lakukan. Studi fenomenologi digunakan agar mendapatkan jawaban dari penelitian dengan cara mengetahui langsung fenomena yang terjadi di lingkungan sosial terhadap objek dari penelitian ini. Dalam penyusunan penelitian ini, peneliti tidak luput dari referensi yang relevan dengan pembahasan penelitian, peneliti juga mengambil referensi dari beberapa karya ilmiah yang telah dibuat oleh penelitipeneliti sebelumnya. 
Diambil dari skripsi Peran Ganda Perempuan pada Ibu Bekerja di Desa Pakembinangun, Pakem, Sleman, Yogyakarta oleh Eka Puspitasari (2016), digambarkan mengenai apakah alasan yang menguatkan perempuan untuk memilih bekerja dan bagaimana perempuan memanfaatkan waktu untuk memerankan peran gandanya di rumah dengan perannya sebagai wanita karier. Hal tersebut yang memberikan peneliti gambaran mengenai bagaimana perempuan memutuskan untuk memilih bekerja dibandingkan hanya menjadi ibu rumah tangga di rumah.

Selanjutnya, dalam jurnal Fenomena Kemiskinan Dari Perspektif Kepala Rumah Tangga Perempuan Miskin (Studi Fenomenologi Tentang Makna dan Penyebab, Serta Strategi Penanggulangan Feminisasi Kemiskinan di Desa Wonorejo, Kecamatan Singosari, Kabupaten Malang) oleh Nur Rois Ahmad, Sanggar Kanto dan Edi Susilo (2015), memberikan gambaran mengenai bagaimana perempuan menjadi seorang kepala rumah tangga di dalam keadaan yang miskin, bagaimana hal tersebut menjadi sebuah permasalahan yang kompleks namun harus diselesaikan oleh kepala rumah tangga seorang perempuan. Dalam jurnal Pengalaman Menjadi Disc Jockey Perempuan (Sebuah Pendekatan Interpretative Phenomenological Analysis) oleh Sari Wulan Ningrum dan Yohanis Franz La Kahija (2016), dibahas mengenai bagaimana seorang wanita yang memiliki kemampuan untuk mengaransement dan memainkan lagu lewat piringan hitam atau turntable selayaknya juga dilakukan oleh laki-laki yang berprofesi sebagai disc jockey. Hal tersebut dilihat menjadi sebuah kesenjangan mengenai apakah pekerjaan sebagai disc jockey hanya dilakukan oleh laki-laki dan bagaimana jika profesi tersebut dilakukan oleh perempuan.

\section{METODE PENELITIAN}

Penelitian ini menggunakan paradigma konstruktivisme. Menurut Eriyanto (2004:13), paradigma konstruksitivisme adalah paradigma dimana kebenaran suatu realitas sosial dilihat sebagai hasil konstruksi sosial, dan kebenaran suatu realitas sosial bersifat relatif. Paradigma konstruktivisme ini berada dalam perspektif interpretivisme (penafsiran) yang terbagi dalam tiga jenis, yaitu interaksi simbolik, fenomenologis dan hermeneutik.

Analisis data kualitatif memiliki peranan penting dalam penelitian, yakni sebagai faktor utama penilaian kualitas penelitian. Kemampuan peneliti memberi makna kepada data merupakan kunci apakah data yang diperolehnya memenuhi unsur valid dan reliabel, yakni data yang diperoleh memiliki hasil jawaban yang sama setelah diuji terusmenerus (Yin, 2009:41).

Dalam penelitian ini, peneliti melakukan teknis analisis data yang bersifat induktif, yakni teknik yang dilakukan untuk menganalisis data dengan cara berkesinambungan, dengan menelaah data dari awal hingga akhir data yang telah dikumpulkan (Santana, 2007:16). 


\section{PEMBAHASAN}

Komunikasi merupakan suatu proses penyampaian pesan dari komunikator kepada komunikannya. Dalam melakukan komunikasi, digunakan suatu media sebagai penyampai pesan. Bahasa merupakan suatu media atau jembatan yang digunakan untuk menyampaikan pesan. Dalam penelitian ini, bahasa adalah salah satu komponen penting ketika peneliti mendalami fenomena yang terjadi. Bahasa yang digunakan oleh para pengemudi ojek online ini adalah bahasa yang digunakan sehari-hari, tetapi peneliti menemukan kosakata-kosakata baru yang menjadi pedoman dalam melakukan penelitian dengan para informan. Kosakata tersebut yang biasa digunakan oleh para pengemudi ojek online di lingkungan sesama pengemudi, untuk menyamai makna dari suatu aktivitas. Berikut beberapa kosakata yang peneliti temukan selama melakukan penelitian bersama para informan:

Tabel 4.3

\begin{tabular}{|c|c|c|}
\hline \\
\hline No. & Kata & Makna \\
\hline 1. & Bonus & $\begin{array}{c}\text { Tambahan yang diberikan kepada pengemudi } \\
\text { ketika mereka berhasil melewati batas atau } \\
\text { sasaran pendapatan yang ditentukan oleh } \\
\text { perusahaan. }\end{array}$ \\
\hline 2. & On-Bid & $\begin{array}{c}\text { Kondisi dimana para pengemudi sedang } \\
\text { mengaktifkan aplikasi ojek onlinenya untuk } \\
\text { mendapatkan orderan dari pelanggan. Kata ini } \\
\text { juga sering digunakan untuk menggambarkan } \\
\text { bahwa mereka sedang melakukan pekerjaannya } \\
\text { di jalanan. }\end{array}$ \\
\hline 3. & Off-Bid & $\begin{array}{l}\text { Kondisi dimana para pengemudi sedang } \\
\text { menon-aktifkan aplikasi ojek onlinenya. Kata } \\
\text { ini juga bermakna bahwa mereka sedang tidak } \\
\text { mengambil orderan pelanggan, atau ketika } \\
\text { mereka sedang beristirahat di sela } \\
\text { pekerjaannya. }\end{array}$ \\
\hline 4. & Order-an & $\begin{array}{l}\text { Pesanan; Kata ini digunakan ketika para } \\
\text { pengemudi mendapatkan pesanan dari } \\
\text { pelanggan melalui aplikasi online. }\end{array}$ \\
\hline
\end{tabular}

\begin{tabular}{|c|c|c|}
\hline 5. & Share Loc & $\begin{array}{l}\text { Singkatan dari share location, yang berarti } \\
\text { membagikan lokasi; Digunakan para } \\
\text { pengemudi untuk membagikan lokasi } \\
\text { keberadaan mereka kepada rekan } \\
\text { komunitasnya ketika sedang menuntaskan } \\
\text { orderan, bertujuan agar dapat membagikan } \\
\text { informasi mengenai keadaan langsung yang } \\
\text { mereka alami. }\end{array}$ \\
\hline 6. & Target & $\begin{array}{l}\text { Sasaran; Kata ini digunakan oeh para } \\
\text { pengemudi ketika sasaran dari pendapatan } \\
\text { minimal yang ditentukan oleh perusahaan } \\
\text { dapat terlampaui, sehingga mereka bisa } \\
\text { mendapatkan bonus. }\end{array}$ \\
\hline 7. & Trip & $\begin{array}{c}\text { Perjalanan; Kata ini digunakan ketika para } \\
\text { pengemudi sedang ada di jalanan } \\
\text { menyelesaikan pesanan dari pelanggan. }\end{array}$ \\
\hline
\end{tabular}

Sumber : Olahan Penulis, 2018

Membahas mengenai sasaran pendapatan, dalam penelitian ini peneliti juga mendapatkan data yang menunjukkan pendapatan yang didapat oleh para pengemudi ojek online ketika mereka dapat mencapai target pendapatan perhari. Dalam perhitungan bonus yang akan didapat, perusahaan Gojek menggunakan sistem poin untuk menghitung jumlah bonus dari setiap pengemudi.

$$
\begin{aligned}
& \square 12 \text { poin }=\operatorname{Rp} 10.000 \\
& \square 16 \text { poin }=\operatorname{Rp} 30.000 \\
& \square 20 \text { poin }=\operatorname{Rp} 40.000 \\
& \square 24 \text { poin }=\operatorname{Rp} 50.000 \\
& \square 30 \text { poin }=\operatorname{Rp} 70.000
\end{aligned}
$$

Setiap order yang diterima oleh pengemudi, mereka akan mendapatkan maksimal tiga poin, dengan bonus maksimal yang akan didapat sebesar Rp 200.000 per harinya.

Sebelum membahas lebih dalam, penulis akan mencoba untuk menghadirkan anggapan atau stereotip yang ada di masyarakat. Meskipun semakin lama zaman semakin 
berkembang, tetapi hal tersebut tidak menjamin pemikiran manusia pun ikut berkembang. Saat ini masih banyak beredar di kalangan masyarakat stereotip mengenai anggapan bahwa kaum perempuan dianggap tabu atau masih dipertanyakan jika mereka memilih untuk bekerja. Tidak sampai situ saja, semakin perempuan menunjukkan eksistensi mereka di masyarakat, semakin banyak pula opini masyarakat yang timbul mengenai alasan mengapa perempuan tersebut memilih untuk bekerja.

Menurut Gudykust dan Kim (Mulyana, 2009:233), manusia antarbudaya adalah orang yang telah mencapai tingkat tinggi dalam proses antarbudaya yang kognisi, afeksi, dan perilakunya tidak terbatas, tetapi terus berkembang melewati parameter-parameter psikologis suatu budaya.

Hal tersebut belum sepenuhnya terjadi dalam masyarakat masa kini, karena stereotip diatas masih saja dicamkan kepada perempuan masa kini yang sudah berusaha menunjukkan kualitas dirinya pada masyarakat.

Stereotipe tersebut selanjutkan dijadikan sebagai parameter untuk mengukur kualitas dari seorang perempuan dalam lingkungan masyarakatnya. Jika mereka dianggap tidak berhasil dalam menunjukkan kualtas diri yang bagus, maka mereka dianggap tidak dapat melampaui laki-laki. Tetapi jika perempuan berhasil, hal tersebut dapat menjadi nilai positif bagi mereka sendiri sehingga dapat membungkam masyarakat mengenai stereotip yang dilabelkan kepada mereka.
Perempuan pada masa kini berusaha menunjukkan eksistensinya dengan mengkonstruksikan dirinya sebagai kaum yang pantas disetarakan oleh kaum laki-laki. Dengan mereka memilih untuk bekerja, hal tersebut sudah merupakan bentuk dari konstruksi dirinya sebagai kaum yang kuat, terlebih ketika mereka memilih pekerjaan yang dalam masyarakat, pekerjaan tersebut merupakan pekerjaan yang dilakukan oleh kaum laki-laki. Ketika kaum perempuan berhasil menjalani pekerjaan sebagai pengemudi ojek online, lingkungan masyarakat mempertanyakan apakah mereka dapat melakukan pekerjaan tersebut seperti lakilaki melakukannya.

Hal tersebut yang mendorong perempuan untuk mengkonstruksikan dirinya sehingga lingkungan tidak lagi mempertanyakan hal tersebut, karena mereka mengetahui bahwa kaum perempuan juga dapat melakukan pekerjaan tersebut sebaik kaum lakilaki, dan hal tersebut dibuktikan oleh informan dalam penelitian ini.

Berdasarkan data yang diperoleh peneliti, informan dalam penelitian ini menggambarkan bagaimana perempuan berjuang dalam hidupnya untuk memperoleh pengakuan dari lingkungannya terhadap apa yang sudah mereka lakukan agar dapat disetarakan dengan kaum laki-laki. Seiring dengan perkembangan zaman, masyarakat mulai menerima keberadaan mereka para perempuan yang telah memilih bekerja dan melakukan pekerjaan yang biasa dilakukan oleh kaum laki-laki. 
Berbagai macam alasan yang melandasi mengapa para perempuan memilih bekerja dibandingkan hanya menjadi ibu rumah tangga di rumahnya. Interaksi simbolik yang terjadi pada diri mereka menjadi dasar dari alasan mengapa mereka memilih keputusan untuk bekerja. Interaksi simbolik adalah suatu aktivitas yang merupakan ciri khas manusia yakni komunikasi atau pertukaran simbol yang diberi makna (Mulyana, 2003: 59). Mead sebagai tokoh yang membahas mengenai interaksi simbolik, membahas pemikirannya mengenai mind, self, dan society. Peneliti kemudian menggunakan pernyataan tersebut dalam meneliti masalah.

Terdapat banyak dorongan yang melandasi pengambilan keputusan, salah satunya dorongan dari dalam diri. Perempuan berfikir untuk memilih bekerja karena akan banyak mendapatkan keuntungan ketika bekerja, dibandingkan hanya berdiam diri di rumah menjadi seorang ibu rumah tangga. Keuntungan yang akan didapat salah satunya adalah dapat membantu suaminya dalam memenuhi kebutuhan keluarga. Selain itu mereka juga dapat mengisi waktu luang dengan hal-hal yang positif dan menghasilkan. Dalam prosesnya, keuntungan lainnya yang bisa didapatkan adalah pengalaman serta koneksi dengan lingkungan baru. Hal tersebut didapatkan secara berbeda ketika hanya menjadi seorang ibu rumah tangga di rumah. Itu pula yang menjadi salah satu dorongan dari dalam diri yang menjadikan alasan bahwa bekerja merupakan hal yang pantas untuk dilakukan oleh seorang perempuan, karena hal tersebut positif dan memberikan keuntungan.

Selanjutnya hal yang mendorong seorang perempuan untuk bekerja adalah dorongan dari dirinya sendiri. Ketika mereka merasa dirinya memiliki keahlian terhadap sesuatu hal atau bidang, mereka mencoba untuk menggunakan keahlian tersebut agar menjadi hal yang positif dan menguntungkan. Selagi mereka merasa bisa menjalankannya, hal itu tidak akan menjadi suatu permasalahan yang berat. Dalam masalah ini, perempuan yang menjadi pengemudi ojek online.

Para perempuan ini merasa dirinya mampu dan memiliki keahlian jika menjadi seorang pengemudi ojek, dan mereka mampu memenuhi persyaratan yang ditentukan untuk dapat menjadi seorang pengemudi ojek online.

Kepribadian yang dimiliki pun mempengaruhi pengambilan keputusan tersebut. Berdasarkan data yang didapat oleh peneliti dari hasil wawancara dan observasi, pengemudi ojek online yang menjadi informan menggambarkan pribadi perempuan yang tangguh. Mereka mampu melakukan pekerjaan yang berat tetapi dengan cara mereka sendiri. Menjadi pengemudi ojek online bukanlah hal yang mudah, yang dibutuhkan bukanlah hanya memiliki kemampuan mengendarai motor, memiliki kelengkapan persyaratan, tetapi harus memiliki mental dan keberanian yang tangguh, karena dalam menjalaninya mereka melalui berbagai macam rintangan. Masalah dan rintangan yang muncul bukan hanya ketika mereka berada di jalanan, tetapi juga bagaimana 
mereka menempatkan diri dalam menjadi seorang pengemudi ojek online.

Ketika memilih menjadi pengemudi ojek online, informan dari penelitian ini memutuskan untuk menjadikan ojek online sebagai mata pencahariannya. Meskipun mereka percaya bahwa ojek online dapat dijadikan pecaharian utama, tetapi salah satunya juga menjadikan ojek online sebagai pekerjaan sampingan yang dapat membantu perekonomian keluarga.

Mengemudi ojek online juga dijadikan sebagai hiburan ketika mereka bertemu dengan rekan sesama pengemudi dan juga customer ketika mengambil orderan. Dari hal tersebut, kemudian lingkungan pun menjadi faktor yang mendorong perempuan ketika memilih untuk bekerja. Faktor lingkungan sebagai pendorong merupakan hal yang sudah dapat diketahui dengan mudah, karena lingkunganlah yang menjadi tempat untuk melakukan segala kegiatan. Lingkungan pun terbagi dalam beberapa macam, yaitu lingkungan internal dan lingkungan eksternal. Lingkungan internal yang mendorong salah satunya adalah keluarga. Alasan mengapa informan menjadi seorang perempuan yang bekerja adalah mereka ingin kebutuhan keluarganya terpenuhi. Meskipun hal tersebut adalah tanggung jawab utama dari seorang suami yang menjadi kepala keluarga, tetapi seorang perempuan juga memikirkan kebahagiaan untuk keluarganya. Lalu dalam proses mengambil keputusan untuk bekerja pun keluargalah yang memberikan dukungan dan persetjuan, apakah ibu atau istrinya diperbolehkan untuk bekerja.
Selanjutnya lingkungan eksternal yang menjadi pemberi nilai terhadap konstruksi yang ditunjukkan oleh para perempuan. Lingkungan eksternal seperti lingkungan rumah, lingkungan kerja, memberikan dorongan kepada informan dalam menjadi seorang pengemudi ojek online. Terdapat banyak komentar negatif yang dilontarkan ketika mengetahui bahwa seorang perempuan memilih bekerja yang pekerjaannya merupakan pekerjaan kaum laki-laki.

Meskipun demikian, hal tersebut dapat dijadikan motivasi dalam membangun diri. Tetapi selain itu banyak pula komentar positif yang dijadikan semangat dalam menjalani pekerjaan. Lingkungan tempat mereka bekerja, seperti komunitas yang dijadikan tempat untuk singgah, menjadi salah satu dorongan untuk terus menjadi pengemudi ojek online ditengah kontra yang disampaikan kepada para informan terhadap pekerjaan yang mereka pilih.

Para pengemudi ojek online ini juga dijadikan motivasi untuk lingkungannya ketika seorang perempuan berhasil menunjukkan bahwa mereka mampu untuk disetarakan dengan kaum laki-laki. Dari data yang didapatkan, lingkungan dari pengemudi ojek online perempuan menjadikan mereka sebagai panutan, karena kemampuan mereka dalam mengkonstruksikan dirinya ketika berada di dalam lingkungan tersebut. Mereka dapat memberikan bukti kepada lingkungannya bahwa kaum perempuan mampu melakukan pekerjaan yang dilakukan oleh kaum laki-laki. Tidak mudah untuk dapat mengetahui bahwa lingkungan masyarakat sudah menerima 
keberadaan dan eksistensinya, tetapi proses yang mereka lalui merupakan suatu usaha yang tidak mudah dan membutuhkan usaha yang gigih. Untuk menjadi seorang perempuan yang mengerjakan pekerjaan dengan resiko yang tinggi, para pengemudi ojek online membutuhkan keberanian yang besar dalam menjalaninya. Mereka menaklukkan jalanan demi mencapai tujuannya ketika memilih untuk menjadi pengemudi ojek online, meskipun mereka mengetahui bahwa tantangan di depan sangat besar. Demi membantu keluarga, demi mendapatkan pengalaman dan lingkungan baru, dan demi mendapatkan pengakuan tentang eksistensi dan kualitas diri, mereka berani mengambil semua resiko dari tantangantantangan tersebut.

Selain menerjang segala resiko yang ada, dalam menjalani semua proses tersebut para pengemudi ojek online perempuan pun juga menemukan manfaat. Mereka dapat mengenal lingkungan baru, menemukan orangorang baru dengan pengalaman yang baru pula. Selain itu, ketika menjadi seorang pengemudi ojek yang dianggap lemah oleh masyarakat karena mereka adalah seorang perempuan, bantuan datang dari lingkungan itu sendiri. Terdapat komunitas yang menjadi tempat bersinggah ketika sedang menlakukan pekerjaan, dan komunitas tersebut pula yang dijadikan sebagai tempat pertolongan ketika sedang dalam masalah. Meskipun demikian, saling menghargai yang ditunjukkan oleh setiap anggota menimbulkan rassa pengertian, keakraban, dan kekeluargaan, sehingga dengan hal tersebut mereka dapat terbantu untuk menunjukkan eksistensi dan kualitas dirinya di masyarakat.

Semakin majunya teknologi informasi, membantu masyarakat untuk memudahkan segala pekerjaan yang harus diselesaikan. Dengan adanya aplikasi online ini, masyarakat dimudahkan dalam memesan alat transportasi yang cepat dan murah. Tetapi tidak semua kalangan masyarakat terbuka dengan berkembangnya hal tersebut.

Penolakan muncul dari kalangan ojek pangkalan. Mereka merasa dengan adanya ojek online tersebut penghasilan mereka menjadi berkurang dan merugikan mereka. Berbagai macam konflik pun bermunculan, mulai dari bentrok antar pengemudi ojek online dengan ojek pangkalan, pembagian zona merah dan zona aman, serta demonstrasi kepada pemerintah kota untuk meminta keadilan terhadap peraturan yang berlaku. Konflik tersebut sukar untuk dihindari ketika para perempuan sudah memilih untuk melakukan pekerjaan ini. Mau tidak mau mereka harus siap jika harus menghadapi masalah seperti itu di jalanan. Keberanian dan kesopanan yang ditunjukkan ketika menghadapi situasi seperti itu, yang membuat para perempuan ini mampu melalui permasalahan tersebut. Mereka dapat menunjukkan bahwa kaum perempuan mampu menghadapi permasalahan tersebut dan mendapatkan penghormatan dari lingkungan sekitar. Rasa segan juga timbul disaat anggota masyarakat sekitar mengetahui bahwa perempuan dapat menaklukkan situasi yang 
sampai sekarang masih saja menjadi suatu kendala dalam menjadi seorang pengemudi ojek online.

\section{SIMPULAN}

Berdasarkan hasil analisis yang sudah dilakukan oleh peneliti, didapati kesimpulan bahwa latar belakang pemilihan profesi sebagai pengemudi ojek online dikonstruksi oleh identitas diri yang berkaitan dengan motivasi dalam dirinya.

Di sisi lain, sebagian masyarakat belum sepenuhnya menerima keberadaan pengemudi ojek online perempuan di Kota Bandung. Kondisi tersebut diketahui dari alasan yang melatarbelakangi para pengemudi ojek online dalam melakukan pekerjaan tersebut. Artinya, secara kapabilitas perempuan membuktikan bahwa dirinya mampu melakukan kerja dan tanggung jawab yang sama dengan laki-laki. Kaitannya dengan posisi sosial di lingkungannya, para informan beralasan bahwa dengan menjadi seorang pengemudi ojek online mereka mendapat pengakuan bahwa mereka mampu memenuhi kebutuhan keluarganya dan membantu suami dalam menafkahi keluarga.

Dari sisi mengkonstruksikan dirinya di lingkungan masyarakat, para pengemudi ojek online merubah stereotip di masyarakat. Pada akhirnya masyarakat menjadi tanggap dengan keberadaan para pengemudi ojek online perempuan. Di sisi lain para pengemudi ojek online perempuan memberikan alternatif bagi konsumen yang merasa tidak nyaman jika dibonceng oleh pengemudi ojek laki-laki. Dengan stereotip lama yang masih beredar di lingkungan, para pengemudi ojek online perempuan dapat menunjukkan eksistensi dan kualitas mereka sehingga mampu disetarakan dengan pengemudi ojek online lainnya yaitu laki-laki.

\section{REFERENSI}

Donny. (2005). Fenomenologi dan Hermeneutika: Sebuah Perbandingan. Kalamenau.

Eriyanto. (2004). Analisis Wacana, Pengantar Isi Media. Yogyakarta: LKIS.

Mulyana, Deddy dan Jalaluddin Rakhmat. (2009). Komunikasi Antarbudaya. Bandung: Remaja Rosdakarya.

Santana K., Septiawan. (2007). Menulis Ilmiah: Metode Penelitian Kualitatif. Jakarta: Yayasan Obor Indonesia.

Yin, Robert K. (2009). Studi Kasus Desain \& Metode. Jakarta.

Sumber lain:

eprints.uny.ac.id/37957/1/skripsi_Eka\%20Pus

pitasari_121022410

19.pdf diakses pada 5 April 2018 pukul

16.53.

http://wacana.ub.ac.id/index.php/wacana/articl

e/download/378/313 diakses pada 21

Oktober 2017 pukul 23.11.

http://ejournal3.undip.ac.id/index.php/empati/a rticle/view/15006/1

4505 diakses pada 23 Oktober 2017 pukul 17.15 .

https://bandungkota.bps.go.id/ diakses pada 7

Desember 2017, pukul 15.21. 